\title{
Honey as an Alternative in the Management of Contemporary Wound Healing: A Systematic Review
}

Dipika Dabas

\begin{abstract}
Introduction: In recent times, the traditional honey has shown a revival as a topical treatment for a variety of wounds. The aim of this systematic review is to assess the available evidence and further evaluate the role of honey in modern wound care management.
\end{abstract}

Methods: The databases which were used for this purpose include the PubMed and the ISI web of science. The review only contains the studies being conducted on humans. The review only contains the studies being conducted on humans covering burns, ulcers and other types of wounds (like traumatic, postoperative, malignant wounds). Under "design," research designs namely, RCTs and CCTs were included.

Result: In all three of the identified wound types, honey as a dressing with healing promoting properties is supported by evidence, whereas, the otherknown properties of honeylike debridement, deodorizing, anti-inflammatory and wound pain-reducing effects are found to be less supported bythe pieces of evidence.

Interpretation: Many limitations were quite evident in the included studies related tothe methodology, quality, and sample size. This review tries to reveal all such limitations and gaps and also recommends certain suggestions forthe future research.

Keywords: Burns, Healing, Honey, Manuka, Pain, Ulcers, Wound.

How to cite this article: Dabas D. Honey as an Alternative in the Management of Contemporary Wound Healing: A Systematic Review: J Health Sci Res 2018;9(2):41-48.

Source of support: Nil

Conflict of interest: None

\section{INTRODUCTION}

Indigenous medicine (also popularly called as traditional medicine) embraces the expertise and information that has been originated in various civilizations over generations before the origin of modern medicine. According to the World Health Organization (WHO), traditional therapies are those practices which incorporate the knowledge and beliefs pertaining to indigenous plants, animals, minerals,

\section{Senior Manager}

Department of Health, Research and Wellness, Vipul MedCorp, Gurugram, Haryana, India

Corresponding Author: Dipika Dabas, Senior Manager, Department of Health, Research and Wellness, Vipul MedCorp, Gurugram, Haryana, India, e-mail: dipikadabas@gmail.com spiritual healing techniques, which are either applied as a combination therapy or sometimes individually to diagnose, treat and prevent the ailments or in nutshell, to maintain a healthy well-being. ${ }^{1}$ Over the last decade, the traditional orindigenous medicines has becomeincreasingly popular $^{2-4}$ and with this rising popularity, the concomitant interest in the scientific community for these therapies has also been observed. Many herbal products have so far been studied and claimed to possess many therapeutic properties. One such natural product of therapeutic promise is honey.

Honey bears a special mention as a medicinal product since ancient times in numerous studies, ,6,6-810 the first such reference was discovered in "Edwin Smith papyrus" (2600-2200 BC) in the wound management followed by Greeks and Romans who used honey for preventing wound decomposition by either adding animal or vegetable fat into it or by incorporating honey into many other ointments. ${ }^{911-13}$ Many other descriptions like using cooked honey as an astringent by the famous Arab doctor, Avicenna (980-1037), for reducing wound exudation, ${ }^{15}$ using honey as a cleanser in case of gunshot wounds are available for the reference. ${ }^{15,16}$ The popularity of honey remained in the picture until the dawn of antibiotics (1940). ${ }^{17,18}$

There has been a profound change observed in the epidemiology of soft tissue infections due to $S$. aureus especially in Maori and Pacific populations in New Zealand. The most commonly affected age group is below 5 years of age group. ${ }^{19,20}$ The prevalence of Methicillin-resistant S. aureus is found to be $8-10 \%$, but it varies in different regions. There is a growing concern of emergence of community-onset MRSA (CA-MRSA) and SWP ST30 (South West Pacific) resistant clones in New Zealand. Apart from their resistance to $\beta$-lactam antimicrobials, their resistance to most commonly used topical fusidic acid in New Zealand is also noteworthy. ${ }^{21}$

Though antibiotics are essential for reducing the worldwide encumbrance due to fast-growing infectious diseases but, it is complementing this fact with the development of antibacterial resistance resulting in the waning effect of antibiotics. All this along with the growing cognizance for natural medicines has shown a revival in the interest for unfurling the antimicrobial and wound healing properties of honey in the scientific community. 5,15,18 
Honey is a viscid, carbohydrate-rich solution collected, altered and stored by the honeybee, Apis mellifera. ${ }^{12}$ The chief constituents of honey are sugar $(75-79 \%)$ and water $(20 \%){ }^{11,13}$ but it also contains proteins, vitamin B-complex, minerals, and antioxidants like flavonoids, vitamin C, enzyme-like invertase, amylase, glucose oxidase and catalase, metals like selenium ${ }^{4,24}$ and organic acids $(0.57 \%)$, which are responsible for its acidic nature. ${ }^{23,24}$ The specific proportions of all these constituents may vary depending on the type of the plant, the season of nectar collection, topography, the age of honey and anytreatment whatsoever done since the time of its harvest. ${ }^{13}$

The immunomodulatory properties of honey relevant to the wound repair are based on many mechanisms. Firstly, its anti-bacterial activity due to the production of hydrogen peroxide by the enzymatic activity on the wound exudates, ${ }^{4,8,23,25}$ secondly, providing less 'free' water for the growth of microbes. The high sugar content of the honey also causes bacterial death due to osmosis. 13,26 The third effect of honey can be explained by its acidic nature (ranging between 3.2 and 4.5) which for bacterial growth is not ideal (7.2-7.4). ${ }^{22,26,27}$

There are many varieties of honey that are wellresearched and sold in the market with different standardization of antibacterial activities like Taulang honey (TH), Manuka honey, Langnese honey, pure unprocessed Indian hive bee honey, pasture honey, jelly bush honey, African jungle honey. Some of the clinically practiced honey include Manuka and Medihoney, although Taulang honey, a multifloral honey from Malaysian jungles is also recently gaining popularity. Unlike Taulang honey, Manuka and Medihoney come from the Leptospermum scoparium (L. scoparium) species of trees in New Zeal and Australia. Manuka honey has generated interest in the scientific world because of its unique antibacterial property which is independent of peroxide activity. ${ }^{28-31}$

Though apitherapy is considered as an ancient therapy and its revival in today's world is quite evident by its frequent use in a variety of conditions, but the exact level of evidence for its role in wound management is still not clear. ${ }^{4,5,18,26,32}$ Thus, the aim of this systematic review is to assess the role of honey in the wound management taking into account the available published literature. This review examines the use of honey in the wound care management, its application in different categories of the wound, and also provides an associated critical evaluation.

\section{METHODS}

The systematic review is designed with randomized controlled trials (RCTs) and clinical controlled trials (CCTs). Two databases, namely PubMed and ISI Web of Science were used as a strategy for the search so that most of the published literature can be covered. The items like "honey, "design" and "wound healing", "ulcers", "burns", were executed in the search engine. Under "design", research designs namely, RCTs and CCTs were included. There were no restrictions being applied with reference to the authors, publication year or the investigating institute. The review only contains the studies being conducted on humans covering burns, ulcers and other types of wounds (like traumatic, post-operative, malignant wounds).

Tables 1 and 2 represent a detailed systematic analysis of the study parameters including the methodologies and their strengths and weaknesses. The six categories for the outcome parameters are presented in Table 3.

\section{RESULTS}

\section{Description of the Publication}

A total of 54 publications were assessed in PubMed and ISI Web of Science (Flow chart 1), out of which 27 studies which were registered for this review for different wound etiologies are presented in Table 4. Though the two publications belong to the same study, in this review, these are included as two different studies as they discuss the primary and secondary outcomes separately. The review does not include any meta-analysis due to the heterogenic nature of the included studies. ${ }^{33,34}$

\section{Outcomes}

The analysis of the included works of literature according to the etiological classification of the wound resulted in the following:

\section{Burns}

Seven of the RCTs in the review have examined the impact of pure, undiluted and unrefined honey in the wounds resulted from burns (Table 1). Although the anti-bacterial effect was found to be positive in five of the RCTs, the statistically significant result was found only in four of them (Tables 1 and 2). Only in one study, the tangential excision (TE) followed by skin grafting in the control group resulted in better anti-bacterial effect than the honey intervention group. ${ }^{40}$

There are six RCTs in the review that examined the wound healing effect of honey, all of which resulted in positive outcomes, thus favoring honey. Three of these studies reported a better and a more rapid process of epithelization, whereas two of these studies showed a catalytic effect in the production of granulation tissue. $^{39,47}$

Though four of the RCTs in the review have silver sulphadiazine (SSD), which is known as a gold standard in wound healing, in the control group, yet honey reported 
Flow chart 1: Number of studies included in the systematic review

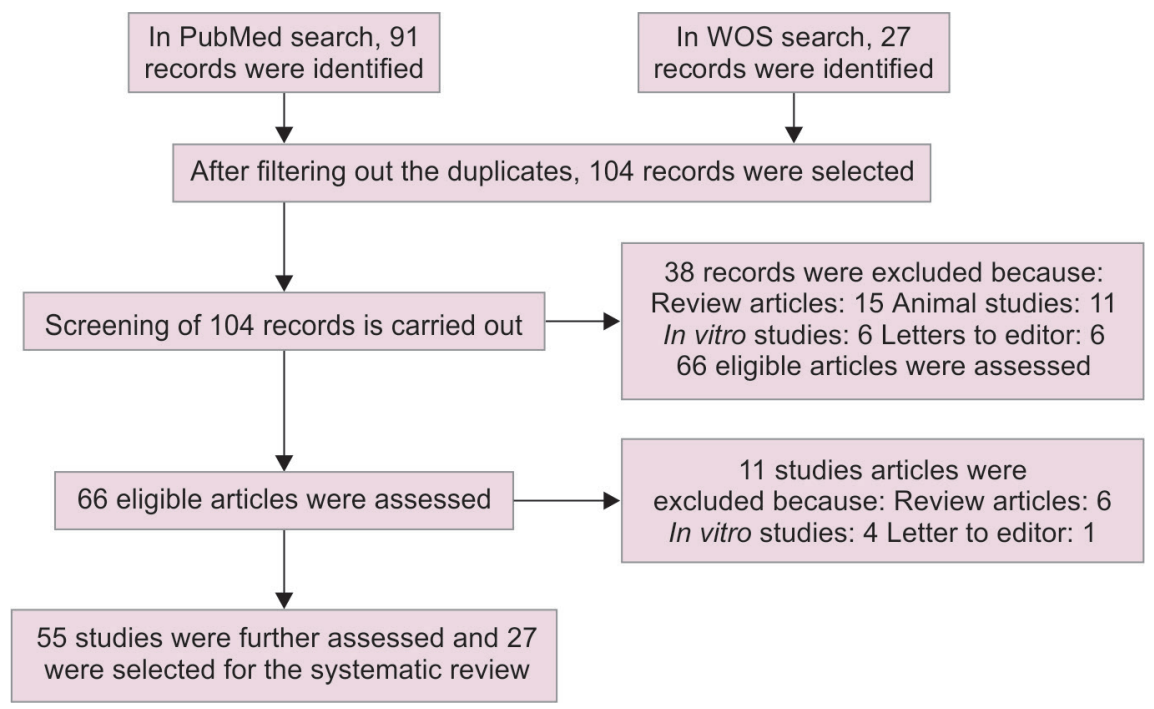

to have a significant and a healthier antibacterial effect when comparing it to SSD (Tables 1 and 2).

The positive outcome in odor reducing, antiinflammatory and the debriding effects of honey was reported in a number of trials (Table 2), but on comparing it with the control group, none of the studies has shown any statistically significant difference (Tables 1 and 2).

As far as wound pain is concerned, 3 RCTs mentioned its effect and only one trial reported a positive outcome in favor of honey (Tables 1 and 2).

It is quite evident from these trials that the antibacterial and the healing effects of honey are favorable, whereas, the debriding, anti-inflammatory, odor as well as the pain reducing effects of honey are found to be rather weak and thus, inconclusive.

\section{Ulcers}

The wide use of honey in a variety of ulcers like venous, pressure, diabetic, and foot ulcer are discussed in 6 trials (Table 3). Four of the RCTs reported the antibacterial effect of honey and only one of it showed a positive outcome with honey, however not so significant statistically. Two studies discussed the potential action of honey in lowering the incidence of infection and in eliminating the methicillin-resistant Staphylococcus aureus (MRSA). ${ }^{33,34}$

Four RCTs reported wound healing stimulating effect of honey, out of which two showed a statistically significant effect, ${ }^{45}$ whereas, the anti-inflammatory, debridement and deodorizing properties of honey are weakly supported by one trial each. ${ }^{38}$

As most of the evidence was found to be positive in case of wound stimulating effect of honey, the other properties of honey in ulcers seemed to be inconclusive.
However, this can be argued as insufficient evidence for its practical implications in clinical practice.

\section{Other Wounds}

There are 14 studies (RCTs) included in this group that belongs to different wound etiologies (Table 3). Out of 14 RCTs, only one study has reported a statistically significant effect on the antibacterial effect of honey ${ }^{50}$ (Table 2), whereas, the healing effects of honey are investigated by 12 RCTs. Four of these trials showed a significant result but the majority of these studies are supporting the healing catalytic effects of honey (Table 2).

The anti-inflammatory properties of honey are discussed in 6 RCTs and the debriding effect is reported in 3 RCTs, where $50 \%$ is found to be statistically significant in the former and only one was found to be favorable in the latter (Table 2).

In wound pain management, there are only two RCTs in the review that support honey out of 5 RCTs, but those are not statistically significant. As the deodorizing effects of honey in these classes of wounds are not well supported by any of the studies, thus its evidence can be referred to as weak (Table 2).

It can be concluded that honey has a substantial effect on the healing process in these types of wounds as compared to the deodorizing, anti-inflammatory, antibacterial and pain reducing properties where the pieces of evidence were found to be insufficient and weak.

\section{DISCUSSION}

After looking at the three above defined wound types, it is quite clear that honey is beneficial as a dressing for the healing of different types of wound. However, there are limited pieces of evidence found in the pieces of literature 
Table 1: Description of the included studies with reference to wound class and design

\begin{tabular}{|c|c|c|c|c|}
\hline $\begin{array}{l}\text { Wound } \\
\text { category }\end{array}$ & Author & Sample size & Intervention used & Wound etiology \\
\hline \multirow[t]{5}{*}{$\begin{array}{l}\text { Ulcers: } \\
\text { RCTs }\end{array}$} & $\begin{array}{l}\text { Gethin and } \\
\text { Cowman }\end{array}$ & $\begin{array}{l}n=108: H G=54 \\
C G=54\end{array}$ & $\begin{array}{l}\text { HG: Manuka Honey, UMF 18+; CG: } \\
\text { hydrogel }\end{array}$ & Venous leg ulcer \\
\hline & $\begin{array}{l}\text { Gethin and } \\
\text { Cowman }\end{array}$ & $\begin{array}{l}n=108: H G=54 \\
C G=54\end{array}$ & $\begin{array}{l}\text { HG: Manuka Honey, UMF 18+; } \\
\text { CG: hydrogel }\end{array}$ & Venous leg ulcer \\
\hline & Jull et al. ${ }^{23}$ & $\begin{array}{l}n=368: H G=187 \\
C G=181\end{array}$ & $\begin{array}{l}\text { HG: Manuka, CG: UMF 12+; standard } \\
\text { dressings }\end{array}$ & Venous and mixed ulcer \\
\hline & Yapucu Gunes ${ }^{59}$ & $\begin{array}{l}n=50 ; H G=15 \\
C G=11 \text { (but in } 26 \\
\text { subjects) }\end{array}$ & $\begin{array}{l}\text { HG: Raw, unpasteurized, natural honey; } \\
\text { CG: Dressing of ethoxy-diaminoacridine } \\
\text { plus Nitrofurazone }\end{array}$ & $\begin{array}{l}\text { Stage } 2 \text { and } 3 \text { pressure } \\
\text { ulcers }\end{array}$ \\
\hline & Shukrimi et al. ${ }^{50}$ & $\begin{array}{l}n=30: H G=14 \\
C G=16\end{array}$ & $\begin{array}{l}\text { HG: Pure and non-sterile honey; CG: } \\
\text { povidone -iodine } 10 \% \text { dressing }\end{array}$ & $\begin{array}{l}\text { Type-2 diabetic foot } \\
\text { ulcer }\end{array}$ \\
\hline $\begin{array}{l}\text { Ulcers: } \\
\text { CCT }\end{array}$ & Oluwatosin et al. ${ }^{38}$ & $\begin{array}{l}n=\text { (but in } 38 \\
50 \text { subjects) }\end{array}$ & $\begin{array}{l}\text { HG: Unprocessed and undiluted honey; } \\
\text { CG: Mixture of phenytoin and honey }\end{array}$ & Ulcer: Post-traumatic \\
\hline \multirow[t]{7}{*}{$\begin{array}{l}\text { Burns: } \\
\text { RCT }\end{array}$} & Baghel et al. ${ }^{6}$ & $\begin{array}{l}n=78 ; H G=37 \\
C G=41\end{array}$ & HG: Pure, undiluted; CG: SSD & $\begin{array}{l}\text { Burns (1st and 2nd } \\
\text { degree) }\end{array}$ \\
\hline & Malik et al. ${ }^{32}$ & $\begin{array}{l}\mathrm{n}=150 \text { (intra- } \\
\text { individual design) }\end{array}$ & HG: Langnese honey; CG: SSD & Burns (2nd degree) \\
\hline & Subrahmanyam ${ }^{45}$ & $\begin{array}{l}n=104 ; H G=52 \\
C G=52\end{array}$ & $\begin{array}{l}\text { HG: Undiluted,pure but unprocessed } \\
\text { honey; CG: SSD }\end{array}$ & $\begin{array}{l}\text { Burns with TBSA }<40 \% \\
\text { (superficial) }\end{array}$ \\
\hline & Subrahmanyam ${ }^{48}$ & $\begin{array}{l}n=92: H G=46 \\
C G=46\end{array}$ & $\begin{array}{l}\text { HG: Undiluted and unprocessed honey ; } \\
\text { CG: Polyurethan film }\end{array}$ & $\begin{array}{l}\text { Burns with TBSA }<40 \% \\
\text { (Partial thickness) }\end{array}$ \\
\hline & Subrahmanyam ${ }^{47}$ & $\begin{array}{l}n=100: H G=50 \\
C G=50\end{array}$ & $\begin{array}{l}\text { HG: Indian hive bee unprocessed, pure } \\
\text { and honey; CG: potato peel (boiled) }\end{array}$ & $\begin{array}{l}\text { Burns with TBSA }<40 \% \\
\text { (Partial thickness) }\end{array}$ \\
\hline & Subrahmanyam ${ }^{49}$ & $\begin{array}{l}n=50 ; H G=25 \\
C G=25\end{array}$ & $\begin{array}{l}\text { HG: Unprocessed, pure and undiluted } \\
\text { honey; CG: SSD }\end{array}$ & $\begin{array}{l}\text { Burns with TBSA }<40 \% \\
\text { (superficial) }\end{array}$ \\
\hline & Subrahmanyam ${ }^{47}$ & $\begin{array}{l}n=50 ; H G=25 \\
C G=25\end{array}$ & $\begin{array}{l}\text { HG: Indian hive bee (unprocessed) } \\
\text { honey; CG: skin graftingand (TE) }\end{array}$ & $\begin{array}{l}\text { Burns with TBSA }<30 \% \\
\text { (full thickness) }\end{array}$ \\
\hline \multirow[t]{10}{*}{$\begin{array}{l}\text { Other: } \\
\text { RCTs }\end{array}$} & Chang et al. ${ }^{11}$ & $\begin{array}{l}\mathrm{n}=48: \mathrm{HG}=16 ; \\
\text { Budesonide } \\
\text { group = 16; } \\
\text { Gentamicin group = } 16\end{array}$ & HG: Manuka CG: saline solution honey; & $\begin{array}{l}\text { Endoscopic sinus } \\
\text { surgery }\end{array}$ \\
\hline & English et al. ${ }^{18}$ & $\begin{array}{l}n=30: H G=14 \\
C G=16\end{array}$ & $\begin{array}{l}\text { HG: Manuka honey, UMF 15; CG: } \\
\text { Wrigley's sugarless chewing gum }\end{array}$ & Gingivitis ulceration \\
\hline & $\begin{array}{l}\text { Lund-Nielsen } \\
\text { et al. }{ }^{29}\end{array}$ & $\begin{array}{l}n=69: H G=34 \\
C G=35\end{array}$ & $\begin{array}{l}\text { HG: Manuka honey, CG:silver-coated } \\
\text { bandage UMF12+; nanocrystalline }\end{array}$ & Malignant wound \\
\hline & $\begin{array}{l}\text { Mclntosh } \\
\text { Thomson }{ }^{30}\end{array}$ & $\begin{array}{l}n=100: H G=52 \\
C G=48\end{array}$ & $\begin{array}{l}\text { HG: Manuka honey; CG: } \\
\text { paraffin-impregnated tulle grass }\end{array}$ & $\begin{array}{l}\text { Surgical wound of } \\
\text { toe-nail }\end{array}$ \\
\hline & Robson et al. ${ }^{41}$ & $\begin{array}{l}n=105: H G=52 \\
C G=53\end{array}$ & $\begin{array}{l}\text { HG: Medihoney; CG: standard } \\
\text { conventional treatment }\end{array}$ & $\begin{array}{l}\text { Eczematous, mixed } \\
\text { wounds }\end{array}$ \\
\hline & Robson et al. ${ }^{40}$ & $\begin{array}{l}n=49: H G=25 \\
C G=24\end{array}$ & $\begin{array}{l}\text { HG: Medihoney, Antibacterial Wound } \\
\text { Gel; CG: conventional dressings }\end{array}$ & $\begin{array}{l}\text { Free tissue grafting for } \\
\text { head and neck cancer }\end{array}$ \\
\hline & Moolenaar et al. ${ }^{33}$ & $\begin{array}{l}n=24: H G=12 \\
C G=12\end{array}$ & $\begin{array}{l}\text { HG: Honeysoft (multifloral) honey } \\
\text { CG: paraffin gauze }\end{array}$ & $\begin{array}{l}\text { Skin toxicity induced by } \\
\text { radiotherapy }\end{array}$ \\
\hline & Mphande et al. ${ }^{36}$ & $\begin{array}{l}n=40: H G=22 \\
C G=18\end{array}$ & HG: Malawi honey; CG: Malawi sugar & $\begin{array}{l}\text { Mixed: trauma, post- } \\
\text { surgical, ulcers }\end{array}$ \\
\hline & Khanal et al. ${ }^{26}$ & $\begin{array}{l}n=40: H G=20 \\
C G=20\end{array}$ & $\begin{array}{l}\text { HG: beehive honey from Western Ghats } \\
\text { (India) CG: lignocaine gel }\end{array}$ & $\begin{array}{l}\text { oral mucosal } \\
\text { inflammation after } \\
\text { radiotherapy }\end{array}$ \\
\hline & Ingle et al. ${ }^{22}$ & $\begin{array}{l}n=82 ; H G=42 \\
C G=40\end{array}$ & HG: Monofloral CG: hydrogel aloe honey; & Traumaticskin lesions \\
\hline
\end{tabular}




\begin{tabular}{|c|c|c|c|c|}
\hline $\begin{array}{l}\text { Wound } \\
\text { category }\end{array}$ & Author & Sample size & Intervention used & Wound etiology \\
\hline & Al-Waili and Saloom 4 & $\begin{array}{l}n=50 ; H G=26 \\
C G=24\end{array}$ & $\begin{array}{l}\text { HG: Undiluted, crude honey; CG: povidone- } \\
\text { iodine gel and } 70 \% \text { ethanol }\end{array}$ & $\begin{array}{l}\text { Postsurgical wounds after } \\
\text { C-section and hysterectomy }\end{array}$ \\
\hline & Abdulrhman et al. ${ }^{1}$ & $\begin{array}{l}n=90 ; \mathrm{HG}=30 \\
\mathrm{CG}=30 ; \mathrm{HOPE}=30\end{array}$ & $\begin{array}{l}\text { HG: Non-sterile Egypt honey; CG: HOPE (a } \\
\text { mixture of propolis, benzocaine gel, olive oil, } \\
\text { and beeswax) }\end{array}$ & $\begin{array}{l}\text { Oral mucosal inflammation } \\
\text { after chemotherapy }\end{array}$ \\
\hline & Okeniyiet al. ${ }^{37}$ & $\begin{array}{l}n=43 ; H G=23 \\
C G=32\end{array}$ & $\begin{array}{l}\text { HG: Crude CG: EUSOL and undiluted } \\
\text { honey }\end{array}$ & Abscess injury \\
\hline Other: CCTs & 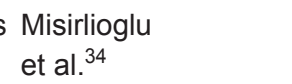 & $\mathrm{n}=88$ & $\begin{array}{l}\text { HG: Unprocessed honey; CG: paraffin and } \\
\text { hydrocolloiddressing }\end{array}$ & Skin graft site of the donor \\
\hline
\end{tabular}

Table 2: Outcomes of the studies with reference to design and wound class.

\begin{tabular}{|c|c|c|c|c|c|c|c|}
\hline $\begin{array}{l}\text { Wound } \\
\text { category }\end{array}$ & Author & $\begin{array}{l}\text { Antibacterial } \\
\text { effect }\end{array}$ & $\begin{array}{l}\text { Healing } \\
\text { catalytic } \\
\text { effect }\end{array}$ & Debridement & $\begin{array}{l}\text { Anti- } \\
\text { inflammatory }\end{array}$ & $\begin{array}{l}\text { Odour } \\
\text { reducing } \\
\text { effect }\end{array}$ & $\begin{array}{l}\text { Wound pain } \\
\text { reducing effect }\end{array}$ \\
\hline Ulcers: & Gethin and Cowman ${ }^{20}$ & $1+$ & $\#$ & \# & $\#$ & \# & $2+$ \\
\hline \multirow[t]{4}{*}{ RCTs } & Gethin and Cowman ${ }^{19}$ & $><$ & $2+$ & $1+$ & \# & \# & \# \\
\hline & Jull et al. ${ }^{23}$ & $/ /$ & $/ /$ & \# & \# & \# & \# \\
\hline & YapucuGunes $^{59}$ & \# & $2+$ & \# & \# & \# & \# \\
\hline & Shukrimi et al. ${ }^{50}$ & // & $/ /$ & \# & $1+$ & $1+$ & $\#$ \\
\hline Ulcers: CCT & Oluwatosin etal. ${ }^{38}$ & \# & $1-$ & \# & $\#$ & $\#$ & \# \\
\hline \multirow[t]{7}{*}{ Burns: RCT } & Baghel etal. $^{6}$ & $2+$ & $2+$ & $1+$ & \# & \# & \# \\
\hline & Malik et al. ${ }^{32}$ & $1+$ & $2+$ & \# & $>1<$ & \# & \# \\
\hline & Subrahmanyam ${ }^{45}$ & $2+$ & $2+$ & $>1<$ & \# & $>1<$ & $1+$ \\
\hline & Subrahmanyam ${ }^{48}$ & $2+$ & $2+$ & $>1<$ & \# & $>1<$ & $>1<$ \\
\hline & Subrahmanyam ${ }^{47}$ & $2+$ & $2+$ & $\#$ & \# & \# & $/ /$ \\
\hline & Subrahmanyam ${ }^{49}$ & $>/<$ & $2+$ & $1+$ & $1+$ & \# & \# \\
\hline & Subrahmanyam ${ }^{47}$ & $\%$ & $\#$ & $\#$ & $\#$ & \# & \# \\
\hline \multirow[t]{13}{*}{ Other: RCTs } & Chang et al. ${ }^{11}$ & \# & $/ /$ & \# & // & \# & \# \\
\hline & Englishetal. ${ }^{18}$ & $>k$ & \# & $\#$ & $2+$ & \# & \# \\
\hline & Lund-Nielsenet al. ${ }^{29}$ & \# & $/ /$ & $/ /$ & // & // & $/ /$ \\
\hline & Mclntoshand Thomson ${ }^{30}$ & \# & $\%$ & $\#$ & $\#$ & $\#$ & $/ /$ \\
\hline & Robson etal. ${ }^{41}$ & \# & $1+$ & $>1<$ & \# & \# & \# \\
\hline & Robson et al. ${ }^{40}$ & $/ /$ & $>/<$ & $\#$ & \# & $>1<$ & \# \\
\hline & Moolenaaret al. ${ }^{33}$ & \# & $1+$ & \# & \# & \# & $1+$ \\
\hline & Mphande et al. ${ }^{36}$ & $1+$ & $1+$ & \# & \# & \# & $1+$ \\
\hline & Khanal et al. ${ }^{46}$ & \# & $2+$ & \# & $2+$ & \# & \# \\
\hline & Ingle et al. ${ }^{22}$ & \# & $1+$ & \# & \# & \# & \# \\
\hline & Al-Waili and Saloom ${ }^{4}$ & $2+$ & $2+$ & \# & $>/<$ & \# & $>1<$ \\
\hline & Abdulrhman et al. ${ }^{1}$ & $\#$ & $2+$ & \# & \# & \# & $\#$ \\
\hline & Okeniyi etal. ${ }^{37}$ & \# & $2+$ & $2+$ & $2+$ & \# & \# \\
\hline Other: CCTs & Misirliogluetal. $^{34}$ & \# & $2+$ & $\#$ & \# & $\#$ & $2+$ \\
\hline
\end{tabular}

1+: result in favor of honey and not significantly different; $2+$ : results significantly different and in favor of honey; \%: results significantly different and in disadvantage of honey; \#: results not reported; $>\mid<:$ not compared; 1 -: results not significantly different and not in favor of honey; //: no significant difference between the honey and ot her therapy regimens

regarding its deodorizing, anti-inflammatory and wound pain-reducing effects.

The antibacterial properties of honey have been shown by the included studies as the strongest, especially in burns. One of the studies has also compared it withTEfollowedbyskin grafting inthird-degreeburns, ${ }^{40}$ where the comparison seems to be inappropriate as the application of topical honey is only recommended in first and second-degree burns (superficial). ${ }^{4,58}$ Nevertheless, these pieces of evidence should be reviewed with caution as out of the 7 RCTs, 5 belonged to the same researcher. Moreover, sixstudies have used undiluted, unprocessed and natural honey which might be seen as an unfavorable fact as far as replication and generalization of future research is concerned.

For the ulcers and other wound categories, the pieces of evidence can be classified from moderate to weak for the anti-bacterial effects of honey. The studies do not support 


\begin{tabular}{llll}
\hline \multicolumn{4}{c}{ Table 3: Wound etiology by design } \\
\hline Wound etiology: & RCT & CCT & Total \\
\hline Ulcer & 5 & 1 & 6 \\
Burns & 7 & 0 & 7 \\
Other wounds & 13 & 1 & 14 \\
Total & 25 & 2 & 27 \\
\hline
\end{tabular}

the much popular recommendation of Manuka and Medi honey for their anti-bacterial function. ${ }^{9,29-31}$ Under ulcer wound category, only three trials (3 RCTs) have used this honey, and only one has reported the antibacterial effect of honey. ${ }^{34}$ Thus, with the limited evidence available for these medical kinds of honey, their recommendations for medical use cannot be established. Moreover, the results from the best-implemented trial by Jull and associates ${ }^{12}$ also confirmed that Manuka honey is not a clinically relevant aid for the wound management when compared to the standard treatment (Table 4).

It can also be commented from this review that the MRSA elimination capacity of honey, as reviewed by few studies ${ }^{29,59}$ can be further investigated in the light of the recent upsurge in the antibiotic resistance. However, this comment should be deduced cautiously as wounds of different etiology are discussed under this wound category; therefore, one may find this conclusion to be difficult to generalize.

In the RCTs on burn wound etiology, thelink between the antibacterial effect and the rapid wound healing is found to be clear as compared to other wound types. This can be interpreted as, in case of burn injuries, there is no other underlying pathology contrary to otherwounds where the chronicity of the wounds poses an influencing effectonthehealing process.

For the treatment protocol, it is important to mention the various considerations like the choice of the honey which was found to be described imprecisely in some studies, for example, in few trials, even the non-sterilized, natural and nonmedical honey was used, which implies that there can be possible risks associated with the contamination. ${ }^{28,31}$ The use of the same type of the standard bandage, the mentioning of the person responsible for changing the dressings and the frequency of its changes make the studies more repeatable. It should be noted that any deviation from the recommended protocol in any investigation degrades its quality and rationality. Such studies should be better avoided for any references.

Honey, as a single therapy, is used only in 10 studies $^{14,28,46,47,53,55,27,39-41}$ and in few studies, it was used after the standard therapy. ${ }^{35}$ This creates challenges in drawing conclusions and thus leads to limitations with reference to repetition and generalization of the outcomes of these studies. The exact arm of the therapy in the studies must be known wherein it is very clear that the research groups have received equal standard therapy and that the

\begin{tabular}{ll}
\multicolumn{2}{c}{ Table 4: Outcome categories } \\
\hline Outcome group & Outcome parameter \\
\hline Antibacterial effect & $\begin{array}{l}\text { Complete eradication or partial } \\
\text { reduction of pathogens } \\
\text { Reanging from reduced wound } \\
\text { size, increased granulation and } \\
\text { epithelialization, reduced healing } \\
\text { time }\end{array}$ \\
Debridement effect & $\begin{array}{l}\text { Reduced debris and necrosed } \\
\text { tissue }\end{array}$ \\
Anti-inflammatory effect & $\begin{array}{l}\text { Reduced signs of inflammation } \\
\text { like redness, swelling, puss } \\
\text { formation } \\
\text { Reduced bad odor }\end{array}$ \\
Deodorizing effect & $\begin{array}{l}\text { Reduced existing pain of the } \\
\text { wound after honey application }\end{array}$ \\
\hline
\end{tabular}

topical intervention (honey or any other control product) is undoubtedly the only variable under investigations. This allows making the clear judgment that the difference in the results is only because of the topical treatment.

The analysis of the cost-effectiveness is also important while we compare the interventions and make a conclusion. In this review, many studies have reported honey as a costeffective treatment, ${ }^{36,37,39,41,48,49}$ but in only one study this was calculated by using the Incremental cost-effectiveness ratio (ICER) factor and the result came out to be in the favor of control group and not the honey group. ${ }^{32}$

\section{Insight on the Methodology of the included Studies}

The sample size varies largely in the included studies and a power analysis was executed in advance in only 11 studies to determine the population size. ${ }^{24,31,33,34,42,51}$

Out of these 11 studies, only 4 studies had the desired number of participants, ${ }^{31,42,49,59}$ and in rest of the 7 studies, 3 RCTs could not gather the required number of subjects owing to the high cost and limited time frame of the study. $^{24,33,34}$ To have the results validated and representative, one must consider in advance the power analysis, predefined selection criteria, primary and secondary outcomes. Unfortunately, these parameters are not clear in case of the included studies in this review. Many studies have used different and nonvalidated measurement tools and thus introduced measurement bias. Although this bias can be corrected by blinding the investigator, ${ }^{58}$ but no such corrections were being implemented in any of these studies.

One of the most commonly encountered limitations in case of using honey in wound care is the inability to blind due to the staining of the wound and the surrounding skin and the apparent smell of honey. ${ }^{31,33}$ Nevertheless, few studies have used single blinding (8 RCTs), $30,31,34,36,38,43,46$ whereas, in some double blinding was done (3RCTs). ${ }^{42,44,49}$ For an independent and qualitative judgment of the outcomes, while assessing the wounds, one must strive for at least a single blinding. ${ }^{57}$ 


\section{Review's Strengths and Weaknesses}

The review discusses about various views on the usage of honey worldwide in 3 different types of wound classes. Moreover, it also highlights the caveats present in the included studies as far as methodology and results are concerned.

The limitation of this review lies in its inability to perform a meta-analysis due to the heterogenic nature of the included studies. As this review includes only the published literature, Jull and associates ${ }^{59}$ mentioned the potential introduction of the publication bias.

\section{FUTURE RESEARCH RECOMMENDATIONS}

On a thorough evaluation of the studies, many gaps have been observed in the review and thus the recommendation of honey in the clinical management of the wound remains inconclusive. It is absolutely necessary to perform the power analysis, stratification of the wound and the simultaneous corrections of the confounding factors. There should be clear mentioning of the type of honey used. Only gamma-sterilized honey-impregnated dressings must be recommended owing to its standard composition and quality besides its easy usage.

The validated and standardized measurement tools along with a reliable cost-effectiveness analysis are also recommended to allow a fair comparison between honey and the standard current practice in the modern wound care management.

The Consort guidelines for the randomized controlled trials must be strictly abided by the investigator while reporting any results.

\section{REFERENCES}

1. World Health Organization. Traditional medicine: Fact sheet N134. 2008. Dec, [Last accessed on 2015 Oct 25]. Available from: http://www.who.int/mediacentre/factsheets/fs134/en/

2. Thomas KJ, Nicoll JP, Coleman P. Use and expendture on complementary medicine in England: a population based survey. Complement Ther Med 2001;9:2-11.

3. The Landmark report on public perceptions of alternative care. Sacramento: Landmark Healthcare Inc; 1998.

4. Subrahmanyam M, Enoch S. Topical application of honey in the treatment of burns. In: Cooper R, Molan P, White R, editors. Honey in modern wound management. Aberdeen:HealthComm UK Limited, trading as Wounds UK Limited; 2009. p. 177-187.

5. Bardy J, Slevin NJ, Mais KL, Molassiotis A. A systematic review of honey uses and its potential value within oncology care. Journal of clinical nursing. 2008 Oct;17(19):2604-2623.

6. Dunford C. The use of honey-derived dressings to promote effective wound management. Professional nurse (London, England). 2005 Apr;20(8):35-38.

7. Leigh Sare J. Leg ulcer management with topical medical honey. British journal of community nursing. 2008 Sep;13(Sup4):S22-S32.

8. Zumla A, Lulat A. Honey-a remedy rediscovered. J R Soc Med. 1989 Jul; 82(7):384-385.
9. Dany-Mazeau M, Pautard G. L'utilisation du miel dans le processus de cicatrisation. De la ruche à l'hôpital. Krankenpflege Soins infirmiers. 1991;84(3):63-69.

10. Jull AB, Cullum N, Dumville JC, Westby MJ, Deshpande S, Walker N. Honey as a topical treatment for wounds. Cochrane Database of Systematic Reviews. 2015(3).

11. Lusby PE, Coombes A, Wilkinson JM. Honey: a potent agent for wound healing? Journal of WOCN. 2002 Nov 1;29(6):295-300.

12. Subrahmanyam M. Honey impregnated gauze versus polyurethane film (OpSiteR) in the treatment of burns-a prospective randomised study. British Journal of Plastic Surgery. 1993 Jan 1;46(4):322-323.

13. Dealey C. Wound management products. In: The care of wounds. A guide for nurses, Third ed., Oxford, UK: Editorial offices: Blackwell Publishing Ltd.; 2005:83-89.

14. Dealey C. German Wound Surgeons 1450-1750. EWMA Journal. 2005;5(2):48-51.

15. Khan FR, Abadin ZU, Rauf N. Honey: nutritional and medicinal value. International journal of clinical practice. 2007 Oct;61(10):1705-1707.

16. Langemo DK, Hanson D, Anderson J, Thompson P, Hunter S. Use of honey for wound healing. Advances in skin \& wound care. 2009 Mar 1;22(3):113-118.

17. Williamson DA, Lim A, Thomas MG, Baker MG, Roberts SA, Fraser JD, Ritchie SR. Incidence, trends and demographics of Staphylococcus aureus infections in Auckland, New Zealand, 2001-2011. BMC infectious diseases. 2013 Dec;13(1):569.

18. Williamson DA, Zhang J, Ritchie S, Roberts S, Fraser J, Baker MG. Staphylococcus aureus disease in New Zealand, 2002011. Emerg Infect Dis, in press.

19. Best Practice Advisory Committee. Management of impetigo. 2009. Available at http://www.bpac.org.nz/BPJ/2009/february/docs/bpj19_impetigo_pages_8-11.pdf

20. Olaitan PB, Adeleke OE, Iyabo OO. Honey: a reservoir for microorganisms and an inhibitory agent for microbes. African health sciences. 2007;7(3).

21. Robson V, Dodd S, Thomas S. Standardized antibacterial honey (Medihoney ${ }^{\mathrm{TM}}$ ) with standard therapy in wound care: randomized clinical trial. Journal of advanced nursing. 2009 Mar;65(3):565-575.

22. Snowdon JA, Cliver DO. Microorganisms in honey. International journal of food microbiology. 1996 Aug 1;31(1-3):1-26.

23. Anderson I. Honey dressings in wound care. Nurs Times 2006;102(22):40-42.

24. Stephen-Haynes J. Evaluation of a honey-impregnated tulle dressing in primary care. British journal of community nursing. 2004 Jun;9(Sup2):S21-27.

25. Ahmed AK, Hoekstra MJ, Hage JJ, Karim RB. Honeymedicated dressing: transformation of an ancient remedy into modern therapy. Annals of plastic surgery. 2003 Feb 1;50(2):143-148.

26. Dunford C, Cooper R, Molan P, White R. The use of honey in wound management. Nursing Standard (through 2013). 2000 Nov 29;15(11):63-68.

27. English HK, Pack AR, Molan PC. The effects of manuka honey on plaque and gingivitis: a pilot study. Journal of the International Academy of Periodontology. 2004 Apr;6(2):63-67.

28. Jull A, Walker N, Parag V, Molan P, Rodgers A. Randomized clinical trial of honey impregnated dressings for venous leg ulcers. British Journal of Surgery. 2008 Feb;95(2):175-182. 
29. Molan PC. Potential of honey in the treatment of wounds and burns. American journal of clinical dermatology. 2001 Feb 1;2(1):13-19.

30. Gethin G, Cowman S. Retracted: Manuka honey vs. hydrogel-a prospective, open label, multicentre, randomised controlled trial to compare desloughing efficacy and healing outcomes in venous ulcers. Journal of clinical nursing. 2009 Feb;18(3):466-474.

31. Gethin G, Cowman S. Bacteriological changes in sloughy venous leg ulcers treated with manuka honey or hydrogel: an RCT. Journal of wound care. 2008 Jun;17(6):241-247.

32. Shukrimi A, Sulaiman AR, Halim AY, Azril A. A comparative study between honey and povidone iodine as dressing solution for Wagner type II diabetic foot ulcers. Med J Malaysia. 2008 Mar;63(1):44-46.

33. Baghel PS, Shukla S, Mathur RK, Randa R. A comparative study to evaluate the effect of honey dressing and silver sulfadiazene dressing on wound healing in burn patients. Indian journal of plastic surgery: official publication of the Association of Plastic Surgeons of India. 2009 Jul;42(2):176-181.

34. Malik KI, Malik MN, Aslam A. Honey compared with silver sulphadiazine in the treatment of superficial partialthickness burns. International Wound Journal. 2010 Oct 1;7(5):413-417.

35. Subrahmanyam M. Topical application of honey in treatment of burns. British Journal of Surgery. 1991 Apr;78(4):497-498.

36. Subrahmanyam M. Early tangential excision and skin grafting of moderate burns is superior to honey dressing: a prospective randomised trial. Burns. 1999 Dec 1;25(8):729-731.

37. Subrahmanyam M. A prospective randomised clinical and histological study of superficial burn wound healing with honey and silver sulfadiazine. Burns. 1998 Mar 1;24(2): 157-161.

38. Chang EH, Alandejani T, Akbari E, Ostry A, Javer A. Doubleblinded, randomized, controlled trial of medicated versus nonmedicated merocel sponges for functional endoscopic sinus surgery. J Otolaryngol Head Neck Surg. 2011 Feb 1;40(suppl 1):S14-19.

39. Robson V, Yorke J, Sen RA, Lowe D, Rogers SN. Randomised controlled feasibility trial on the use of medical grade honey following microvascular free tissue transfer to reduce the incidence of wound infection. British Journal of Oral and Maxillofacial Surgery. 2012 Jun 1;50(4):321-327.

40. Moolenaar M, Louwrens Poorter R, Paulus Gerardus Van Der Toorn P, Willem Lenderink A, Poortmans P, Cornelis Gerardus Egberts A. The effect of honey compared to conventional treatment on healing of radiotherapy-induced skin toxicity in breast cancer patients. 2006;45(5):623-624.

41. Mphande AN, Killowe C, Phalira S, Wynn Jones H, Harrison WJ. Effects of honey and sugar dressings on wound healing. Journal of wound care. 2007 Jul;16(7):317-319.

42. Khanal B, Baliga M, Uppal N. Effect of topical honey on limitation of radiation-induced oral mucositis: an intervention study. International journal of oral and maxillofacial surgery. 2010 Dec 1;39(12):1181-1185.

43. Ingle R, Levin J, Polinder K. Wound healing with honey-a randomised controlled trial. South African Medical Journal. 2006;96(9):831-835.

44. Al-Waili NS, Saloom KY. Effects of topical honey on postoperative wound infections due to gram positive and gram negative bacteria following caesarean sections and hysterectomies. European journal of medical research. 1999 Mar;4(3):126-130.

45. Abdulrhman M, Samir Elbarbary N, Ahmed Amin D, Saeid Ebrahim R. Honey and a mixture of honey, beeswax, and olive oil-propolis extract in treatment of chemotherapy-induced oral mucositis: a randomized controlled pilot study. Pediatric hematology and oncology. 2012 Mar 30;29(3):285-292.

46. Okeniyi JA, Olubanjo OO, Ogunlesi TA, Oyelami OA. Comparison of healing of incised abscess wounds with honey and EUSOL dressing. Journal of Alternative \& Complementary Medicine. 2005 Jun 1;11(3):511-513.

47 Misirlioglu A, Eroglu S, Karacaoglan N, Akan M, Akoz T, Yildirim S. Use of honey as an adjunct in the healing of split thickness skin graft donor site. Dermatologic surgery. 2003 Feb;29(2):168-172.

48. Günes ÜY, Eser I. Effectiveness of a honey dressing for healing pressure ulcers. Journal of Wound Ostomy \& Continence Nursing. 2007 Mar 1;34(2):184-190.

49. Tijani LA, Onyechi HU. A comparison of topical honey and phenytoin in the treatment of chronic leg ulcers. African journal of medicine and medical sciences. 2000 Mar;29(1):31-34.

50. Lund-Nielsen B, Adamsen L, Kolmos HJ, Rørth M, Tolver A, Gottrup F. The effect of honey-coated bandages compared with silver-coated bandages on treatment of malignant wounds - a randomized study. Wound Repair and Regeneration. 2011 Nov;19(6):664-670.

51. Subrahmanyam M. Honey dressing versus boiled potato peel in the treatment of burns: a prospective randomized study. Burns. 1996 Sep 1;22(6):491-493.

52. Brusselaers N, Pirayesh A, Hoeksema H, Richters CD, Verbelen J, Beele H, Blot SI, Monstrey S. Skin replacement in burn wounds. Journal of Trauma and Acute Care Surgery. 2010 Feb 1;68(2):490-501

53. Dunford CE. Treatment of a wound infection in a patient with mantle cell lymphoma. British Journal of Nursing. 2001 Aug 13;10(16):1058-1065.

54. Gottrup F, Apelqvist J, Price P, editors. Outcomes in controlled and comparative studies on non-healing wounds: recommendations to improve the quality of evidence in wound management. Journal of wound care. 2010 Jun;19(6): 237-268.

55. McIntosh CD, Thomson CE. Honey dressing versus paraffin tulle gras following toenail surgery. Journal of wound care. 2006 Mar;15(3):133-136.

56. Baghel PS, Shukla S, Mathur RK, Randa R. A comparative study to evaluate the effect of honey dressing and silver sulfadiazene dressing on wound healing in burn patients. Indian journal of plastic surgery: official publication of the Association of Plastic Surgeons of India. 2009 Jul;42(2): 176-181.

57. Moher D, Hopewell S, Schulz KF, Montori V, Gøtzsche PC, Devereaux PJ, Elbourne D, Egger M, Altman DG. CONSORT 2010 explanation and elaboration: updated guidelines for reporting parallel group randomised trials. International journal of surgery. 2012 Jan 1;10(1):28-55.

58. Wilkinson JM, Simpson MD. High use of complementary therapies in a New South Wales rural community. Aust J Rural Health 2001;9:166-171.

59. White R. The benefits of honey in wound management. Nursing Standard. 2005 Nov 16;20(10):57-66. 